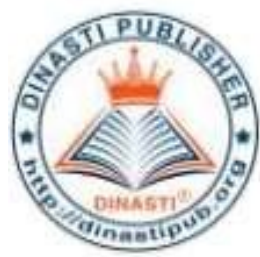

\title{
VALUE ANALYSIS SERVICES THROUGH PUBLIC RELATIONS IN MARKETING, INTEGRATED MARKETING COMMUNICATIONS, AND IMAGE PERSONAL SATISFACTION TO IMPROVE THE COMMUNITY
}

\section{Bachtiar Sembiring}

Universitas Tama Jagakarsa. Jakarta. Indonesia

\begin{tabular}{|c|c|}
\hline $\begin{array}{l}\text { ARTICLE INFORMATION } \\
\text { Received: } 1 \text { February } 2020 \\
\text { Revised: } 7 \text { February } 2020 \\
\text { Issued: } 11 \text { February } 2020 \\
\text { Corresponding author: } \\
\text { Bachtiar Sembiring }\end{array}$ & $\begin{array}{l}\text { Abstract: The problem in this study is an indication } \\
\text { of public dissatisfaction at the performance of West } \\
\text { Java Provincial Parliament, it is seen from the } \\
\text { aspiration slow implementation of the legislative } \\
\text { function is less precise, long aspiration process, and } \\
\text { less emotionally satisfying society. The purpose of } \\
\text { this study was to investigate and analyze: The } \\
\text { influence of public relations in marketing, integrated } \\
\text { marketing communications, and personal image } \\
\text { together against the value of service. The influence of } \\
\text { public relations in the marketing, integrated } \\
\text { marketing communication, personal image, and the } \\
\text { value of service together to the satisfaction of the } \\
\text { people. The method used is the method descriptive } \\
\text { survey and explanatory survey method. The type of } \\
\text { investigation used is causality, ie the type of research } \\
\text { that suggested a causal relationship between the } \\
\text { independent variable, in this case, the public relations } \\
\text { in the marketing, integrated marketing } \\
\text { communications, and image personal to the } \\
\text { dependent variable, the value of community service } \\
\text { and satisfaction. The unit of analysis of this research } \\
\text { is the organization which meant Governmental } \\
\text { Organization (NGO). While the unit of observation is } \\
\text { the chairman/member of the NGO in West Java as } \\
\text { many as } 285 \text { people. Managerial implications of this } \\
\text { research is public relations in the marketing of which } \\
\text { is reflected by the "solidify aspirations of the people" } \\
\text { (X4), integrated marketing communication that is } \\
\text { reflected by the "donation for the community" (X12), } \\
\text { and the image of the person being reflected by the } \\
\text { "power of orientation of the party" (X15 ) is proven } \\
\text { to increase the value of the service which is reflected }\end{array}$ \\
\hline
\end{tabular}


by the "valuable information" (Y3) with a contribution of $55 \%$. Public relations in the marketing of which is reflected by the "solidify aspirations of the people" (X4), integrated marketing communication that is reflected by the "donation for the community" (X12), personal image that is reflected by the "power of party orientation" (X15).

Keywords: Value Services, Public Relations in Marketing, Integrated Marketing Communications, Personal Image, Public Satisfaction

\section{INTRODUCTION}

One of the changes that are the result of the movement against the new order is a change to the system of local government, local government system after a new round of reforms has been more hopeful for the realization of justice and equity for the community. With the enactment of Law No. 22 and 25 of 1999 on Local Government and Financial Balance between Central and Regional that has been replaced by Law No. 32 and 33 in 2004.

Sofyan Arief (2012) states that Act has been delegated the power both politically and administratively to the region for the implementation of the authority in accordance with the initiatives and community initiatives in areas other than 6 (six) authority is the authority of the central government, among others, foreign policy, monetary and national fiscal, religion, defense, security, and judicial. Delegation of authority that it was called the "autonomy". Devolution was automatically also moved the political focus to the area as the center of power is not only monopolized by the central government as in the era of centralization yet been distributed to the regions.

Delegation of authority was accompanied by granting greater powers to the House of Representatives / DPRD in performing the function Legislation, Budgeting, and Controlling. Because it is expected by the "Autonomous Region" Regional Representatives Council / Parliament can increase the role of local rule-making by the legal needs of the community in the area.

However, the process transition behavior toward authority that is transparent, participatory and accountable in the exercise of power requires instrument and the most appropriate instrument to realize that change is the law of Roscoe Pound as the opinion of the Law is a tool of Social engineering. If we put the law as an instrument of social engineering then inevitably will fine-tune the legislation in a very important position in organizing power and society. In this case, the role of the written law or regulation at the local level is very important. The use of written law as a tool of social engineering seems to have become the hallmark of a modern constitutional state, as the opinion of sociologist Marc Galentar law regarding characteristics of modern law (Garner, 2004), namely:

a. Modern law consists of rules are applied in a way that does not vary everywhere. Applicability rules are territorial and do not 'private'.

b. Legislation transactional modern. The rights and obligations are given value according to the results of the transaction (in the form of contracts, losses, etc.) between the parties one by the other party.

c. Methods-modern legal norms are universality;

d. These systems are hierarchical;

e. These systems are regulated bureaucratic;

f. This system is rational; 
g. The system is run by the jurist;

h. This system is more technical and complex. Growth of specialized professional intermediaries to contact the court with people who have to deal with it. Attorney's general intermediary;

i. This system can be changed;

j. This system was political;

k. The task of making laws and apply them in circumstances of a technical nature and distinguished officials from other government functions. There is a separation between the legislative, executive and judicial clearly.

Transition at the local level should have been initiated by the Regional

Representatives Council (DPRD) through the preparation of regional regulation are oriented primarily to make changes to the system of local governance that is transparent, accountable and participatory and to protect potential and wisdom of local (Local Wisdom) present their respective regions.

Regional Representatives Council (DPRD) under Law No. 22 of 2003 concerning the composition and the MPR / DPR / D / DPD and Law 32 of 2004 on Regional Government has the power to make the Regional Regulation (Perda) to the House of Representatives (DPRD) as stated in the third chapter of Article 77 of the function of Parliament is "the Provincial Parliament has a function:

a. legislation;

b. budget; and

c. supervision.

While article 78 regulates the duties and authority of parliaments, "Provincial Parliament has the duty and authority to:

a. Forming local regulations are discussed with the provincial government for approval together;

b. Establish a provincial budget together with the provincial government;

c. Carry out supervision on the implementation of regional legislation and other regulations, the Governor's decision,

d. Budget, local government policy in implementing the program

e. regional development, and international cooperation in the area.

f. Propose the appointment and dismissal of the Governor / Deputy Governor to the Minister of the Interior;

g. Give opinion and consideration to the provincial government to international agreements concerning the interests of the region, and;

h. Ask the governor to account for information report in the implementation of decentralized tasks.

The provision is also regulated in Law No. 32 of 2004 on Regional Government in Article 41 "Parliament has a legislative function, budgeting, and supervision". And Article 42 which reads Parliament has the duty and authority to:

a. Forming local regulations are discussed with the governor for approval together;

b. Establish a provincial budget together with the governor;

c. Carry out supervision of the implementation of local regulations and other legislation, the governor's decision, the policy of local governments to implement local development programs and international cooperation in the area.

d. Propose appointment and dismissal of the regent/vice regent or mayor/deputy mayor to the Minister of the Interior through the governor;

e. Give opinion and consideration to the local government district/city to international agreements concerning the interests of the region; and ask the governor to account for information reports in the implementation of decentralized tasks. 
However, legislation in the area of power shift from the executive to the legislative productivity has not been accompanied by an increase in the Council Regulation product region derived from the initiative of Parliament, that is what has been happening in the West Java Provincial Parliament. The draft Regulation West Java Provincial still more came from the executive from the legislature, then where is the urgency of such a shift if the shift was not accompanied by an increase in both the quality and quantity of local regulations on the initiative of Parliament.

Based on the function of Parliament itself, namely the legislative, budgetary, and oversight in West Java province, should increased community satisfaction, because the administration can provide a good service to the community and supervised by Parliament and Council can formulate legislation to support public services. But in fact, the satisfaction of the people in Parliament is decreasing. Performance is deemed respondents Parliament has to function well with the said agreed by 35.20 percent, 27.20 percent do not agree, do not know 37.60 percent. 37.60 percent and the number who do not know indicates that there are people still do not know the duties and functions of Parliament.

While respondents agreed that the quality of Parliament adequately only $33.60 \%$, did not agree and do not know 36.8029 .60 also shows that people are less concerned about the quality of its legislative resources. It also shows a trend towards the less satisfied community in Parliament.

The next statement, related moral credibility of Parliament. 26.40 percent of respondents agree, disagree 37.28 percent and 36.32 percent did not know, so this shows that the morality of legislators is very doubtful by the respondent. It is also a testament to the tendency of dissatisfied people in the West Java Provincial Parliament.

Meanwhile, related to the commitment of Parliament in their aspirations, respondents who had agreed only 31.36 percent, 32.64 percent disagreed and 36 percent did not know. This means that Parliament considered less aspirational by respondents.

Including the assessment of the seriousness is not in the parliament supported the elimination of corruption, which was agreed by 24.80 percent, 39.84 percent disagree and do not know 35.36 percent, thus showing that the Parliament given the respondents is not serious in pushing eradication $\mathrm{CCN}$.

The survey, conducted by the random sampling method and the interview results from 625 respondents with data collection and questionnaires in each village. As for the age of the respondents between the ages of $17-70$ years old with a variety of social and religious status.

Based on the tables above, shows that people tend to be less satisfied with the legislators, especially in the performance of Parliament in the (legislation, budgets, and controls), quality of Parliament, Parliament's commitment to the aspirations of the community, as well as the seriousness of parliaments in eradicating corruption.

Haksever, Render, Russel, and Murdick, (2000: 131-132) and Raval (1996; 19-30), stating that the organization engaged in the service (service) using the marketing mix strategy services to assist them in achieving the value of services / consumer high according to the consumer (customer value), which ultimately determines the performance marketing. Based on the above statement, the low satisfaction of the people thought to be caused by the value of service of local legislators in carrying out its functions. It can be seen from the survey results Indonesian Survey Institute (LSI) in 2012.

A survey conducted by the Indonesian Survey Institute (2012) concerning the representation of the aspirations, indicating there is a considerable gap between the aspirations of the voters with the attitudes and actions of political parties. A total of $65 \%$ of the public stated that the political parties do not represent their aspirations for a variety of public issues: the social class position of the party, the issue of ideology and legal system, and economic issues. Only about $35 \%$ of voters perceived aspirations represented by the attitude and behavior of seven major political parties. 
In roughly the same proportions, voters feel that political parties far more perform actions that only benefit certain groups, and only benefit the party leaders, not voters in general. Because of this low-level representation, as perceived by voters, only a few of the voters who feel they have psycho-political ties with political parties. Only about $23 \%$ of voters who identify themselves with a particular political party. The implications of all of that are changing the map of public support to political parties. Where the public support to almost all of the seven major parties has decreased, except PDIP rose. However, the general level of public support to political parties decreased.

Lovelock \& Wright (2002: 69), states that the service elements that can be responded to by the customer in the delivery of services are the marketing mix, product, price/cost, place, promotion/communication, physical support, process, and contract personnel.

In conjunction with the marketing of services, the Personal Image people which serves as a service provider greatly affect the quality of services provided, the decision of the people associated with this means of selection (election of members of parliament by the people), training, motivation, and human resource management.

Based on the above, it is very important and interesting for a study of the ministry held parliament, in this case, the public relations in the marketing, integrated marketing communications, and personal image to increase the value of service and to build people's satisfaction on legislators.

\section{LITERATURE REVIEW}

It is a public relations activities designed to support the goals of service to the community. The dimensions of public relations in marketing are communication with the public, real activity in the community, Influencing society, Confirming the aspirations of the community, Build relationships with people, Maintaining relations with the community, and taking into account the conditions of the community.

value is enabled, which means that people can do something with the Parliament services. For example, legislation that supports the community. value relationship, ie the value created Parliament by way of a good relationship with the community, the value of community is the value created through community established by Parliament, the value of the experience is the value created through an interesting experience so that the experience is not forgotten in the period the long one.

Public relations in marketing, supported by communication and activities, influence and establish, build and maintain relationships with the community to increase the value for the public service of members of parliament. So based on the above description can be presumed that the public relations in the marketing effect on the value.

Integrated marketing communications in this study are a personal communication afforded by a particular party in conducting elections to continue as deputy members of the party have been sitting in Parliament as lawmakers about the advantages of the party and the party's legislators in bringing the aspirations of the people. The indicator of integrated marketing communications is a medium, massage, mission, \ personal promotion, sales promotion (donations to the public).

Integrated marketing communications right, and in accordance with the reality that is accepted by society, then the value of the service members of the legislature will increase in the hearts of the people, because the media used is easily accessible by the public, the message delivered informative for the community, the mission is communicated lead to good relations between the legislative with the community. So it can be expected that integrated marketing communications affect the value of service.

Image Personal is defined as a picture or view and the impression created in the mind of many people completely and thoroughly about the existence of the institution legislation, to provide information that is meaningful regarding the institutions and the real effect on people's 
willingness to vote for parties and candidates for the DPRD. The dimensions are the focus of the bearer party, The effectiveness of the handling of aspiration, the Strength orientation of the party, the party Experience, Strength party's tradition, and the prestige Achievement party.

, When people leave a good impression on members of Parliament, that the party that carried him trustworthy, folksier in addressing the aspirations of the people (not the song select), orientation of the party supporting him in accordance with the interests of the community, the experience of the bearer party associated both with the community, the strength of the tradition of the party that upholds honesty, prestige achievement bearer party good, then the value will increase service legislators. Because it can be presumed that Personal Image effect on the value of service.

Public relations in marketing, supported by communication and activities, influence and establish, build and maintain relationships with the community to increase the value for the public service of members of parliament. So based on the above description can be presumed that the public relations in the marketing effect on the value of service.

Integrated marketing communications right, and in accordance with the reality that is accepted by society, then the value of the service members of the legislature will increase in the hearts of the people, because the media used is easily accessible by the public, the message delivered informative for the community, the mission is communicated lead to good relations between the legislative with the community. So it can be expected that integrated marketing communications affect the value of service.

When people leave a good impression on members of Parliament, that the party that carried him trustworthy, folksier in addressing the aspirations of the people (not the song select), orientation of the party supporting him in accordance with the interests of the community, the experience of the bearer party associated both with the community, the strength of the tradition of the party that upholds honesty, prestige achievement bearer party good, then the value will increase service legislators. Because it can be presumed that Personal Image effect on the value of service.

Based on the above statement, it is clear that the allegedly jointly in marketing public relations, integrated marketing communications, Personal Imagery and affect the value of service.

Public relations in marketing, supported by communication and activities, influence and establish, build and maintain relationships with the community to improve the satisfaction of the people, where the people's satisfaction is an evaluation process to convey the aspirations of return or the decision to perform aspiration on legislators experienced up this time, not only on a certain aspiration which is supported by the aspiration of people's satisfaction, community satisfaction at the implementation of the legislative function, satisfaction of the people in a rational and emotional satisfaction of the people, which will then be used in this study.

Based on the above, it can be presumed that the public relations in the marketing effect on people's satisfaction.

Integrated marketing communications right, and in accordance with the reality that is accepted by society, then the value of the service members of the legislature will increase in the hearts of the people, because the media used is easily accessible by the public, the message delivered informative for the community, the mission is communicated lead to good relations between the legislative with the community. So it can be said that integrated marketing communications affect the satisfaction of the people, in which the satisfaction of the people supported by the satisfaction of the people on aspiration, the satisfaction of the people in the implementation of the legislative function, satisfaction of the people rationally and emotionally community satisfaction.

Because it can be presumed that integrated marketing communications affect the satisfaction of the people. When people leave a good impression on members of Parliament, that the party that carried him trustworthy, folksier in addressing the aspirations of the people 
(not the song select), orientation of the party supporting him in accordance with the interests of the community, the experience of the bearer party associated both with the community, the strength of the tradition of the party that upholds honesty, achievement of good prestige bearer party, the people's satisfaction will increase. Because it can be presumed that Personal Image effect on people's satisfaction.

The value of service to the community is a value that is acceptable to society of the ratio between issued society with the benefits provided by the institution in this case is that the government and parliament, which consists of the value of the ease and access of ease for the public either through NGOs or directly to express their aspirations them., value-based option, which was created through the opportunity given to the public to select the various options available from the service of members of parliament, the value of information is characterized by ease public to obtain information about the services offered Parliament, the value of the association is the value obtained by the public through feeling or a positive impression of the service due to having gained the satisfaction of the service. enabling value, which means that the public can do something with the Parliament services. For example, legislation that supports the community. value relationship, ie the value created Parliament by way of a good relationship with the community, the value of community is the value created through community established by Parliament, the value of the experience is the value created through an interesting experience so that the experience is not forgotten in the period the long one.

Based on the above, it can be presumed that the value of service affects the satisfaction of the people. The satisfaction of the people supported by the satisfaction of the people on aspiration, the satisfaction of the people in the implementation of the legislative function, satisfaction of the people rationally and emotionally community satisfaction.

Public relations in marketing, supported by communication and activities, influence and establish, build and maintain relationships with the community to improve the satisfaction of the people, where the people's satisfaction is an evaluation process to convey the aspirations of return or the decision to perform aspiration on legislators experienced up this time, not only on a certain aspiration which is supported by the aspiration of people's satisfaction, community satisfaction at the implementation of the legislative function, satisfaction of the people in a rational and emotional satisfaction of the people, which will then be used in this study. Based on the above, it can be presumed that the public relations in the marketing effect on people's satisfaction.

Integrated marketing communications right, and in accordance with the reality that is accepted by society, then the value of the service members of the legislature will increase in the hearts of the people, because the media used is easily accessible by the public, the message delivered informative for the community, the mission is communicated lead to good relations between the legislative with the community. So it can be said that integrated marketing communications affect the satisfaction of the people, in which the satisfaction of the people supported by the satisfaction of the people on aspiration, the satisfaction of the people in the implementation of the legislative function, satisfaction of the people rationally and emotionally community satisfaction. Because it can be presumed that integrated marketing communications affect the satisfaction of the people.

When people leave a good impression on members of Parliament, that the party that carried him trustworthy, folksier in addressing the aspirations of the people (not the song select), orientation of the party supporting him in accordance with the interests of the community, the experience of the bearer party associated both with the community, the strength of the tradition of the party that upholds honesty, achievement of good prestige bearer party, the people's satisfaction will increase. Because it can be presumed that Personal Image effect on people's satisfaction.

The value of service to the community is a value that is acceptable to society of the ratio between issued society with the benefits provided by the institution in this case is that the 
government and parliament, which consists of the value of the ease and access of ease for the public either through NGOs or directly to express their aspirations them., value-based option, which was created through the opportunity given to the public to select the various options available from the service of members of parliament, the value of information is characterized by ease public to obtain information about the services offered Parliament, the value of the association is the value obtained by the public through feeling or a positive impression of the service due to having gained the satisfaction of the service. enabling value, which means that the public can do something with the Parliament services. For example, legislation that supports the community. value relationship, ie the value created Parliament by way of a good relationship with the community, the value of community is the value created through community established by Parliament, the value of the experience is the value created through an interesting experience so that the experience is not forgotten in the period the long one. Based on the above, it can be said that the value of service affects the satisfaction of the people. The satisfaction of the people supported by the satisfaction of the people on aspiration, the satisfaction of the people in the implementation of the legislative function, satisfaction of the people rationally and emotionally community satisfaction.

\section{RESEARCH METHODS}

Upon consideration of the purpose of the study, this research is descriptive and verification. Descriptive research is research that aims to obtain a description of the characteristics of variables. The nature of verification research wanted to test the truth of a hypothesis that is carried out through data collection in the field. Which in this study to test whether public relations in marketing, integrated marketing communications, and personal image of an effect on the value of community service and satisfaction. Given the nature of this research is descriptive and verification conducted through data collection in the field, the research method used is the method descriptive survey and explanatory survey method. The type of investigation used is causality, namely the type of research that suggested a causal relationship between the independent variable, in this case, the public relations in the marketing, integrated marketing communications, and image personal dependent variable, the value of community service and satisfaction. The unit of analysis of this research is the organization which meant Governmental Organization (NGO). While the unit of observation is the chairman/member of the NGO in West Java since NGOs also write your full attention on Parliament's performance in delivering the aspirations of the people. Governmental Organization (NGO). While the unit of observation is the chairman/member of the NGO in West Java since NGOs also write your full attention on Parliament's performance in delivering the aspirations of the people. Governmental Organization (NGO). While the unit of observation is the chairman/member of the NGO in West Java since NGOs also write your full attention on Parliament's performance in delivering the aspirations of the people.

Judging from the time horizon of his, this study is cross-sectional, ie information from the majority of the population (the sample of respondents) were collected directly at the scene empirically, in order to know the opinion of the majority population of the object being studied, as proposed by (Sekaran 2003; 161). The study was conducted in August 2018 untill, 2019.

Population Governmental Organization is as much as 984 NGOs / CBOs which is a sampling frame, the unit of observation is the member/chairman of the NGO / CBOs (name NGOs / CBOs attached).

The sampling used was simple random sampling, so that the characteristics of the sample can represent the characteristics of the population. In this study, the sample size (sample size) adapted to the analysis used, given the data analysis using structural equation modeling (SEM), the sample size for this purpose at least 4-10 times the number of observation variables (observable variables) - (Bachrudin \& tubing, 2002: 34). 
From the results of operations of the variable that refers to the theories presented by experts, it is known that the indicators of variables public relations in the marketing, communications integrated marketing, image personal service, value of service, and satisfaction of the people, as many as 31 indicators (see table operationalization of variables).

Based on the purpose of this study is to measure the influence of independent variables (public relations in marketing, integrated marketing communications, and the image of personnel) to the dependent variable (satisfaction community), involving an intervening variable (value of the service), then the approach to modeling and solution techniques are used as analysis tools (tools of analysis) in this dissertation is to use the Structural Equation Model (SEM). The reasons for selecting this method is its ability to measure the construct indirectly, ie through the indicators and simultaneously analyze the indicator variables and latent variables.

\section{FINDINGS AND DISCUSSION}

Research hypothesis testing will be conducted on each of these hypotheses sequentially starting from the first hypothesis (H1) on the influence of public relations in the marketing (MH) to the value of the service (NP); The second hypothesis (H2), the effect of integrated marketing communications (KP) to the value of the service (NP); The third hypothesis (H3), the influence of personal image (CM) to the value of the service (NP); The fourth hypothesis (H4), about the influence of marketing public relations (PR), an integrated marketing communications (KP), and personal image (CM) jointly against the value of the service (NP); The fifth hypothesis (H5), the influence of public relations in the marketing $(\mathrm{MH})$ to the satisfaction of the people (KM); The sixth hypothesis (H6), the effect of integrated marketing communications (KP) to the satisfaction of the people (KM); seventh hypothesis (H7), the influence of personal image (CM) to the satisfaction of the people (KM); eighth hypothesis (H8), the influence of the value of service (NP) to the satisfaction of the people (KM); Hypothesis ninth (H9), the influence of marketing public relations (PR), an integrated marketing communications (KP), personal image (CM), and the value of service together to the satisfaction of the people (KM).

Based on Table 1 below, The above calculations will then be presented test parameter $\lambda$ (loading factor) measurements on the model of exogenous and endogenous. This test is intended to determine whether or not a strong indicator of their respective latent variables (constructs). Testing parameter $\lambda$ is the standardized regression coefficients (standardized regression weight) of the exogenous and endogenous variables as shown in Table 1 below.

Table 1. Compliance Test Measurement Model

\begin{tabular}{|c|c|c|c|c|c|c|}
\hline \multicolumn{2}{|c|}{ Measurement Model } & \multirow{2}{*}{$\begin{array}{l}\text { The } \\
\text { coefficient } \\
\text { weighting } \\
\text { factor }\end{array}$} & \multirow{2}{*}{$\begin{array}{l}\text { Standar } \\
\text { d Error } \\
\text { (SE) }\end{array}$} & \multirow[b]{2}{*}{$\begin{array}{l}\text { T } \\
\text { value }\end{array}$} & \multirow[b]{2}{*}{$\begin{array}{l}\text { Test } \\
\text { results ( }> \\
\text { 2) }\end{array}$} & \multirow[b]{2}{*}{$\mathbf{R 2}$} \\
\hline Construct & $\begin{array}{l}\text { Var. } \\
\text { Manifest }\end{array}$ & & & & & \\
\hline \multirow{7}{*}{$\begin{array}{l}\text { Marketing } \\
\text { public } \\
\text { relations } \\
(\mathrm{PR})\end{array}$} & $\mathrm{X} 1$ & 0.71 & 0044 & $16: 17$ & Significant & $0: 50$ \\
\hline & $\mathrm{X} 2$ & 0.61 & 0047 & $13: 00$ & Significant & $0: 37$ \\
\hline & $\mathrm{X} 3$ & $0: 53$ & 0045 & 11.62 & Significant & $0: 28$ \\
\hline & $\mathbf{X 4}$ & $\mathbf{0 . 8 1}$ & 0040 & $20: 34$ & Significant & 0.66 \\
\hline & $\mathrm{X} 5$ & 0.79 & 0041 & $19: 52$ & Significant & 0.62 \\
\hline & $\mathrm{X} 6$ & 0.76 & 0042 & $18: 14$ & Significant & $0: 58$ \\
\hline & $\mathrm{X} 7$ & 0.79 & 0039 & $20: 10$ & Significant & 0.62 \\
\hline \multirow{3}{*}{$\begin{array}{l}\text { Integrated } \\
\text { marketing } \\
\text { communic }\end{array}$} & $\mathrm{X} 8$ & 0.74 & 0041 & 17.82 & Significant & $0: 55$ \\
\hline & $\mathrm{X9}$ & 0.72 & 0041 & $17: 40$ & Significant & $0: 52$ \\
\hline & $\mathrm{X} 10$ & 0.63 & 0044 & $14: 36$ & Significant & $0: 40$ \\
\hline
\end{tabular}




\begin{tabular}{|c|c|c|c|c|c|c|}
\hline \multirow{2}{*}{$\begin{array}{l}\text { ations } \\
\text { (KP) }\end{array}$} & $\mathrm{X} 11$ & 0.68 & 0044 & $15: 58$ & Significant & $0: 46$ \\
\hline & $\mathrm{X} 12$ & 0.77 & 0041 & 18.62 & Significant & $0: 59$ \\
\hline \multirow{7}{*}{$\begin{array}{l}\text { Personal } \\
\text { image } \\
(\mathrm{CM})\end{array}$} & $\mathrm{X} 13$ & 0.67 & 0046 & $14: 59$ & Significant & $0: 45$ \\
\hline & X14 & $0: 51$ & 0050 & $10: 23$ & Significant & 0.26 \\
\hline & X15 & 0.74 & 0042 & 17.63 & Significant & $0: 55$ \\
\hline & X16 & $0: 48$ & 0050 & $9: 50$ & Significant & $0: 23$ \\
\hline & $\mathrm{X} 17$ & $0: 44$ & 0051 & $8: 55$ & Significant & $0: 19$ \\
\hline & $\mathrm{X} 18$ & $0: 49$ & 0050 & 3.72 & Significant & $0: 24$ \\
\hline & $\mathrm{x} 19$ & 0.62 & 0047 & $13: 14$ & Significant & $0: 38$ \\
\hline \multirow{8}{*}{$\begin{array}{l}\text { Value of } \\
\text { the service } \\
\text { (NP) }\end{array}$} & Y1 & $0: 55$ & 0052 & 10.61 & Significant & $0: 30$ \\
\hline & Y2 & $0: 54$ & 0052 & $10: 37$ & Significant & $0: 29$ \\
\hline & Y3 & 0.68 & 0048 & $14: 22$ & Significant & $0: 46$ \\
\hline & $\mathrm{Y} 4$ & $0: 58$ & 0051 & $11: 47$ & Significant & $0: 34$ \\
\hline & Y5 & $0: 50$ & 0049 & $10: 22$ & Significant & $0: 25$ \\
\hline & Y6 & $0: 53$ & 0048 & $11: 12$ & Significant & $0: 28$ \\
\hline & Y7 & $0: 43$ & 0053 & $8: 17$ & Significant & $0: 18$ \\
\hline & Y8 & $0: 53$ & 0048 & $11: 17$ & Significant & $0: 28$ \\
\hline \multirow{4}{*}{$\begin{array}{l}\text { The } \\
\text { satisfactio } \\
n \text { of the } \\
\text { people } \\
(\mathrm{KM})\end{array}$} & Y9 & 0.70 & 0043 & $16: 24$ & Significant & $0: 49$ \\
\hline & Y10 & 0.73 & 0043 & 17:01 & Significant & $0: 53$ \\
\hline & Y11 & 0.75 & 0042 & $18: 07$ & Significant & $0: 56$ \\
\hline & Y12 & 0.77 & 0042 & $18: 58$ & Significant & $0: 59$ \\
\hline
\end{tabular}

Source: Results of processing LISREL 8:30 
Based on Table 1 above, it appears that all the $\mathrm{t}$ values of indicators forming the latent variable are greater than $2(t>2)$. According to hear, at.all (2003) when the value of $t>1.98$ $(t>2)$, it can be said all indicators forming latent variables (exogenous and endogenous) is significant, in other words, it can be said that indicator indicators of meaningful and significant in shaping latent variables. So all the indicators in this study can be analyzed further because it can form the latent variables.

Based on table 1 above, The above calculations will then be proposed testing parameters $\gamma$ and $\beta$ (loading factor) structural model of exogenous and endogenous. This test is intended to determine the causal relationship or influence the latent variables to other latent variables, a strong indicator of whether or not each of the latent variables (constructs). Testing parameters $\gamma$ and $\beta$ are standardized regression coefficients (standardized regression weight) to exogenous or endogenous.

\section{The influence of public relations in marketing, integrated marketing communication, personal image, and the value of service to community satisfaction}

In this section will be testing the hypothesis about the influence of exogenous variables in the marketing public relations $(\xi 1)$, an integrated marketing communications exogenous variables $\left(\xi_{2}\right)$, and the personal image of the exogenous variables on endogenous variables satisfaction of the people ( 2 ) through endogenous variable value services $\left(\begin{array}{l}1 \\ \text { ) either partially }\end{array}\right.$ or together. Results obtained by using lisrel program for structural equation model, consistent with the hypothesis put forward is:

$\mathrm{KM}=\mathrm{NP}+0: 260: 30 * * * \mathrm{KP} \mathrm{MH}+0: 15+0: 55 * \mathrm{CM}$, Errorvar. $=0: 35, \mathrm{R}^{2}=0.65$

Based on structural equation 2 above shows the influence of the value of service to community satisfaction is 0.30 , then the influence of public relations in the marketing variables to the satisfaction of the people is 0.26 , the effect of integrated marketing communications to the satisfaction of the people is at 0,15 , and the influence of personal image to the satisfaction of the people is at 0.55 .

Furthermore, the great contribution of the variables in marketing public relations, integrated marketing communication, personal image, the value of services together on community satisfaction is at $65 \%$, the remaining $35 \%$ is influenced by other factors. Thus the people's satisfaction positively influenced by public relations in marketing, integrated marketing communication, personal image, and the value of service.

Public relations in marketing, supported by communication and activities, influence and establish, build and maintain relationships with the community to improve the satisfaction of the people, where the people's satisfaction is an evaluation process to convey the aspirations of return or the decision to perform aspiration on legislators experienced up this time, not only on a certain aspiration which is supported by the aspiration of people's satisfaction, community satisfaction at the implementation of the legislative function, satisfaction of the people in the process of aspiration, and the satisfaction of the people emotionally, which will then be used in this study. Based on the above, it can be said that public relations in the marketing effect on people's satisfaction.

Integrated marketing communications right, and in accordance with the reality that is accepted by society, then the value of the service members of the legislature will increase in the hearts of the people, because the media used is easily accessible by the public, the message delivered informative for the community, the mission is communicated lead to good relations between the legislative with the community. So it can be said that integrated marketing 
communications affect the satisfaction of the people, in which the satisfaction of the people supported by the satisfaction of the people on aspiration, satisfaction of the people in the implementation of the legislative function, satisfaction of the people in the process of aspiration and emotional satisfaction of the people. Because it can be said that integrated marketing communications affect the satisfaction of the people.

When people leave a good impression on members of Parliament, that the party that carried him trustworthy, folksier in addressing the aspirations of the people (not the song select), orientation of the party supporting him in accordance with the interests of the community, the experience of the bearer party associated both with the community, the strength of the tradition of the party that upholds honesty, achievement of good prestige bearer party, the people's satisfaction will increase. Because it can be said that the image of the personal effect on people's satisfaction.

The value of service to the community is a value that is acceptable to society of the ratio between issued society with the benefits provided by the institution in this case is that the government and parliament, which consists of the value of the ease and access of ease for the public either through NGOs or directly to express their aspirations them., value-based option, which was created through the opportunity given to the public to select the various options available from the service of members of parliament, the value of information is characterized by ease public to obtain information about the services offered Parliament, the value of the association is the value obtained by the public through feeling or a positive impression of the service due to having gained the satisfaction of the service. enabling value, which means that the public can do something with the Parliament services. For example, legislation that supports the community. value relationship, ie the value created Parliament by way of a good relationship with the community, the value of community is the value created through community established by Parliament, the value of the experience is the value created through an interesting experience so that the experience is not forgotten in the period the long one. Based on the above, it can be said that the value of service affects the satisfaction of the people. The satisfaction of the people supported by the satisfaction of the people on aspiration, the satisfaction of the people in the implementation of the legislative function, satisfaction of the people in the process of aspiration and emotional satisfaction of the people.

Therefore from the above description, it can be said that community relations in marketing, integrated marketing communication, personal image, and the value of service proven effect on people's satisfaction.

Based on the above results, the findings of this study is the satisfaction of the people in the Parliament of West Java Province will increase mainly people's satisfaction emotionally (Y12) if DPRD of West Java province is able to improve the image of the personal members, especially in the aspect of the strength of the orientation of the bearer party in defending the community (X15) and has a value of service especially high in the level of ease of public access to the information (Y3), where the value of the service will be higher if the company is able to build public relations in the marketing, especially the level of seriousness in establishing the aspirations of the people (X4) and integrated marketing communications, especially inaccuracy in the distribution of donations/support (X12).

\section{CONCLUSION AND SUGESTION}

1. Public relations in the marketing of which is reflected by the "solidify aspirations of the people" (X4), integrated marketing communication that is reflected by the "donation for the community" (X12), and the image of the personal being reflected by the "power of orientation of the party" (X15) is proven to increase the value of service which is reflected 
by the "value information" (Y3) with a contribution of 55\%.

2. Public relations in the marketing of which is reflected by the "solidify aspirations of the people" (X4), integrated marketing communications that by "donations for the people" (X12), the image of personal being reflected by the "power of orientation of the party" (X15), and value-added services reflected by "value information" (Y3) shown to increase the satisfaction of the people as reflected by the "emotional satisfaction" (Y12) with a contribution of $65 \%$. is the most dominant Enhancing community satisfaction.

\section{REFERENCE}

Aaker. Kumar, 1996, Marketing research, John Willey \& Sons Inc., New York.

Achim Walter, Thomas Ritter. 2003. The influence of adaptations, service value, and commitment on trust functions of customer relationships. Journal of Business \& Industrial Marketing. ISSN: 0885-8624 Year: Aug 2003 Volume: 18 Issue: 4/5 Page: 353-365 DOI: 10.1108 / 08858620310480250 Publisher: MCB UP Ltd.

Alan Cowling, Karin Newman, 2005. Banking on people: TQM, service value and human resources. Journal: Personnel Review. ISSN: 0048-3486. Year: Nov 2005 Volume: 24 Issue: 7 Page: 25 - 40. DOI: 10.1108 / 00483489510095789 . Publisher: MCB UP Ltd

Alves, Helena, and Mario Raposo. 2010. The Influence of University Image on Student Behavior. International Journal of Educational Management. Vol. 24 No. 1, Emerald Group PL.

Arikunto Suharmini. 2002, Management Research, Rineka Reserved.

Avery M. Abernethy, Daniel D. Butler, 2003. Promoting customer contact people: a key difference in service and product advertising. Journal of Services Marketing. ISSN: 0887-6045 Year: March 2003 Volume: 7 Issue: 1DOI: 10.1108 / 08876049310026051 Publisher: MCB UP Ltd

Bachrudin, Achmad and Hope L Tobing. 2002. For Research Survey Data Analysis by Using LISREL 8. The Statistics Department of the Science Faculty Padjadjaran University. Bandung.

Barnes, James G. 2001. Secrets of Customer Relationship Management: it's All About How You Make Them Feel, McGraw-Hill: New York.

Bateson, John, E, G, 2001, the Managing Service Marketing, Third Edition Orlando Dryden.

Belanger, Charles, Joan Mount and Mathew Wilson, 2002. Institutional Image and Retention. Tertiary Education and Management 8: 217-230.

Bennet, Anthony R, 2007, The five Vs - a buyer's perspective of the marketing Mix, Journal of Marketing Intelligence and Planning, MCB University Press, 151-156, London 
Berry, Leonard L., and A. Parasuraman, 1991, Marketing Services, Macmillan Inc., Eglinton Avenue East, New York.

Belch, George E., and Michael A. Belch, 2009, Advertising and Promotion: An Integrated Marketing Communications Perspective, 4th Edition, Irwin McGraw Hill, Singapore

Bilson. Simamora. 2005, Multivariate Analysis of Marketing., Jakarta: PT. Gramedia Pustaka Science

Blaug, Ricardo, Louise Horner, and Rohit Lekhi. 2012. Public values, politics and public management. Literature Review. The Work Foundation. The USA.

Buttle, F, 1997, SERVQUAL: Review, Critique, Research Agenda, European Journal of Marketing, vol. 30, no.1.

Chatura Ranaweera, Jaideep Prabhu. 2003. The influence of satisfaction, trust and switching barriers on customer retention in a continuous purchasing setting. International Journal of Service Industry Management. ISSN: 0956-4233 Year: Oct 2003 Volume: 14, Issue: 4 Page: 374-395 DOI: 10.1108 / 09564230310489231 Publisher: MCB UP Ltd.

Chwen Sheu, Roger McHaney, Sunil Babbar. 2003. Service process design flexibility and customer waiting time. Journal: International Journal of Operations \& Production Management. ISSN: 0144-3577. Year: Aug 2003 Volume: 23, Issue: 8 Page: 901 - 917. DOI: 10.1108 / 01443570310486347 . Publisher: MCB UP Ltd.

Clow, Kenneth E. and Donald baack 2007, Integrated Advertising, Promotion, and Marketing Communication, Prentice-Hall, New Jersey.

Egan, John. 2001.Relationship Marketing: Exploring Relational Strategies in Marketing, Prentice Hall: Malaysia.

Eklof \& Cassel, 2001. Marketing. USA: Prentice-Hall.

Damian Hine, Neal Ryan. 2001. Small service firms - creating value through innovation. Journal: Managing Service Quality. ISSN: 0960-4529. Year: Dec 2001 Volume: 9 Issue: 6 Page: 411 - 422. DOI: 10.1108 / 09604529910302109. Publisher: MCB UP Ltd.

David A. Collier. 2005. Modeling the relationships between process value process errors and overall service performance. Journal: International Journal of Service Industry Management. ISSN: 0956-4233. Year: Oct 2005 Volume: 6 Issue: 4 Page: 4 - 19. DOI: 10.1108 / 09564239510096876. Publisher: MCB UP Ltd

David Potts, 2003. The new People's Network service. Journal: VINE. ISSN: 0305-5728 Year: Sep 2003 Volume: 33 Issue: 3 Page: 115 - 118. DOI0.1108 / 03055720310510080. Publisher: MCB UP Ltd.

Fitzsimmons, James A, and Mona J. Fitzsimmons. 2006. Service Management for Competitive Advantage. McGraw-Hill International Editions., New York. 
Gargouri, Ezzedine and Alain d'Astous, 2001, the Consumer evaluations of brand imitations, European Journal of Marketing, Vol 36 No. 1/2, pp. 153-167, MCB University Press, London.

Garner, Mattsson. 2004. Using Service Process Models to Improve Service value:: Examples from New Zealand. Journal: Managing Service Quality.ISSN: 0960-4529.Year: Mar 2004 Volume: 4 Issue: 1 Page: 47 - 52.DOI:Publisher: MCB UP Ltd.

Gordon, H., Ian.2002.Competitor Targeting, Winning The Battle For Customer And Market Share. Canada: John Wiley \& Sons.

Griffin, Jill. 2002.Customer Loyalty: How to Earn It, How to Keep It, New and Revised Edition. McGraw-Hill: Kentucky.

Grönroos, Christian, 2001 The perceived service quality concept - a mistake ?, Journal of Managing Service Quality, Volume 11 No. 3, pp. 150-152, MCB University Press, London.

Groth, John, 1995, Important factors in the sale and pricing of services, Management Decision; Volume 33 No. 7, MCB University Press, London.

HA Kartiwa. 2006. Services Legislative Council. Partners Media Discourse. Jakarta

Halbrook. 1999. Value to the Customer. Total Quality Management. Emerald Backfile. London.

Haksever, Cengiz, Berry Render, Roberta S Russell, and Robert G Murdick 2000, Service Management and Operation, Second Edition, Prentice-Hall International, USA.

Hawkin, Del I, Roger J. best, and Kenneth A.Coney, 2000, Consumer Behavior, Building Marketing Strategy, Eighth Edition, McGraw-Hill, United State.

Hee-Woong Kim, Young-Gul Kim.2001. Rationalizing the customer service process. Journal: Business Process Management Journal. ISSN: 1463-7154. Year: May 2001 Volume: 7 Issue: 2 Page: 139 - 156. DOI: 10.1108 / 14637150110389713. Publisher: MCB UP Ltd.

Helena, Alfes. 2010. The Measurement of Perceived Value in Higher Education: a unidimensional approach. Universidade Da Beira Interior.

Hennig Thurau, Thorsten, and Alexander Klee, 2002. The Impact of Customer Satisfaction and Relationship Quality on Customer Retention: A Critical reassessment and Model Development. Psychology \& Marketing, John Wiley \& Sons, Inc.

Heskett, James, L and W. Earl Sasser, JR, and Leornad A. Schlesinger, 1997, The Service Profit Chan, The Free Press, New York. 
Hoffman, K. Douglas, and John EG Bateson. 1997. Essentials of Services Marketing. The Dryden Press: Fort Worth.

Hoffman, K. Douglas, Scooth W Kelley, and Holly M Rotalsky, 1995, Tracking service failure and employee Recovery Efforts, The Journal of Service Marketing, vol 92 things 4951.

Howard Marmorstein, Dan Sarel, M. Walfried Lassar. 2001. Increasing the persuasiveness of a service guarantee: the role of service process evidence. Journal: Journal of Services Marketing. ISSN: 0887-6045. Year: Oct 2001 Volume: 15 Issue: 2 Page: 147 - 159. DOI: Publisher: MCB UP Ltd.

Hunt, John, 2001 Important factors in the sale and pricing of services, Management Decision; Volume 33 No. 7, MCB University Press, London.

Indra Perwira. 2006. Methods of local elections. Rineka Reserved. Jakarta.

Jaebeom Suh, Swinder Janda, Seo Sunhee. 2006. Exploring the role of culture in developing trust with service providers. Journal of Services Marketing. ISSN: 0887-6045 Year: 2006 Volume: 20 Issue: 4 Page: 265-273 DOI: 10.1108 / 08876040610674607 Publisher: Emerald Group Publishing.

Jeff Hess, John Story. 2005. Trust-based commitment: multidimensional consumer-brand relationships. Journal of Consumer Marketing. ISSN: 0736-3761 Year: Oct 2005 Volume: 22, Issue: 6 Page: 313-322 DOI: 10.1108 / 07363760510623902 Publisher: Emerald Group Publishing.

Jefkins, Frank. 2004. Public Relations. Jakarta: PT. Erland.

Joseph J. Cronin, Michael K. Brady, Richard R. Brand, Roscoe Hightower Jr., Donald J. Shemwell. 2006. A cross-sectional test of the effect and conceptualization of service value. Journal: Journal of Services Marketing. ISSN: 0887-6045. Year: Dec 2006 Volume: 11 Issue: 6 Page: 375 - 391. DOI: 10.1108 / 08876049710187482. Publisher: MCB UP Ltd.

Johnson, C., William, Richard J.Chalva.2001.Total Quality In Marketing. Si Singapore: St.Lucia Press.

Karl J. Mayer, John T. Bowen, Margaret R. Moulton. 2003. A proposed model of the descriptors of the service process. Journal: Journal of Services Marketing. ISSN: 08876045. Year: Nov 2003 Volume: 17 Issue: 6 Page: 621 - 639. DOI: 10.1108 / 08876040310495645. Publisher: MCB UP Ltd

Kotler, Philip, and Keller, 2012, Marketing Management, 14ed, Prentice Hall International, Inc. A Division of Simon \& Schuster, Englewood Cliffs, Nj07632.

Kristina Heinonen, Tore Strandvik. 2005. Communication as an element of service value. Journal: International Journal of Service Industry Management. ISSN: 0956-4233. 
Year: Oct 2005 Volume: 16, Issue: 2 Page: 186 - 198. DOI: 10.1108 / 09564230510592306. Publisher: Emerald Group Publishing Limited.

Kuei, Chu-Hua, 1999, the Internal Service Quality- An Empirical Assessment, International Journal of Quality \& Reliability Management, Vol. 16 No. 8, pp. 783-791, London.

Laurie Jerome, Brian H. Kleiner. 2005. Employee morale and its impact on service value: what companies do to create a positive service experience. Journal: Managing Service Quality. ISSN: 0960-4529. Year: Dec 2005 Volume: 5 Issue: 6 Page: 21 - 25. DOI: 10.1108 / 09604529510104356. Publisher: MCB UP Ltd

Liliana L. Bove, Lester W. Johnson. 2000. A customer-service worker relationship models. Journal: International Journal of Service Industry Management. ISSN: 0956-4233 Year: Dec 2000 Volume: 11 Issue: 5 Page: 491-511 DOI: 10.1108 / 09564230010360191 Publisher: MCB UP Ltd.

Long-Yi Lin, Lu Ching-Yuh 2010, The influence of a corporate image, relationship marketing, and trust on purchase intention. Journal of Marketing. EmeraldLibrary. London.

Lovelock, Christopher, H, and Lauren. K. Wright, 2002, Service Marketing and Management, Prentice Hall International, Inc. New Jersey.

LSI, 2012. On the representation of the aspirations, indicating there is a considerable gap between the aspirations of the voters with the attitudes and actions of political parties. Indonesian Survey Institute.

LSP, 2012. The views of Respondents Regarding Parliament Performance in the Run function with Good. Survey July 25 s / d August 5th, 2012.

Mardiasmo. 2007. The role and functions of Parliament. Salemba Four. Jakarta.

Martijn Hesselink, Frits van den Assem. 2002. Building people and organizational excellence: the Start service value of the program. Journal: Managing Service Quality. ISSN: 09604529. Year: June 2002 Volume: 12 Issue: 3 Page: 139 - 145. DOI: 0.1108 / 09604520210429196. Publisher: MCB UP Ltd

Maureen Eastgate. 2000. Businesses profit through people. Journal: Industrial and Commercial Training. ISSN: 0019-7858. Year: Sep 2000 Volume: 32 Issue: 5 Page: 161 - 163. DOI: 10.1108 / 00197850010345782 . Publisher: MCB UP Ltd

Michael K. Brady, Christopher J. Robertson. 2001. An exploratory study of service value in the USA and Ecuador. Journal: International Journal of Service Industry Management. ISSN: 0956-4233. Year: Dec 2001 Volume: 10 Issue: 5 Page: 469 - 486. DOI: 10.1108 / 09564239910289003. Publisher: MCB UP Ltd.

Minkiewicz, Jody Joanna Evans and Kerrie Bridson. 2009. Co-creation in the heritage sector ANZMAC: Sustainable Management and Marketing. Melbourne 
Nader Baroukh, Brian H. Kleiner, 2002. Recruitment and training of public Servants. Journal: Management Research News. ISSN: 0140-9174. Year: March 2002 Volume: 25, Issue: 3 Page: 28 - 42. DOI: Publisher: Barmarick Publications.

Nguyen, Nha and Gaston LeBlanc. 2001. The mediating role of corporate image on customers' retention decisions an investigation in financial services. International Journal of Bank Marketing. Volume 16, page 52- 65. MCB. London.

Payne, Adrian and Sue Holt. Diagnosing Customer Value: A Review of the Literature and Frame Work for Relationship Management. Canfield Working Paper.

Peng, Norman, and Chris Hackley. 2007. Political marketing communications planning in the UK and Taiwan. Marketing Intelligence \& Planning Vol. 25 No. 5, 2007 pp. 483-498 q Emerald Group Publishing Limited 0263-4503 DOI 10.1108 / 02634500710774950

Peter J. Danaher, Jan. Mattsson. 2004 Customer Satisfaction during the Service Delivery Process. Journal: European Journal of Marketing. ISSN: 0309-0566. Year: May 2004 Volume: 28, Issue: 5 Page: 5 - 16. DOI: 10.1108 / 03090569410062005. Publisher: MCB UP Ltd.

Pratibha A. Dabholkar, Jeffrey W. Overby. 2005. Linking service process and outcome to service value and customer satisfaction evaluations: An investigation of a real estate agent service. Journal: International Journal of Service Industry Management.ISSN: 0956-4233. Year: Mar 2005 Volume: 16Issue: 1Page: 10-27DOI: 10.1108 / 09564230510587131.

PR Smith. 2008. Internet Marketing author, Trainer, and Consultant. Paul launched. The USA.

Ravald, Annika and Christian Grönroos, 1996, the value concept and relationship marketing, European Journal of Marketing, Vol. 30, No.2, pp 19-30, MCB University Press, London.

Reicheld, Redich. 2001 Loyalty Rules, Journal of Marketing Vol. 68 N0. 5, 2004;

Renald Kasali. 2003. Public Relations Management. Graffiti. Jakarta.

Ricky Ryssel, Thomas Ritter, Hans Georg Gemünden. 2004. The impact of information technology deployment on trust, commitment and value creation in business relationships. Journal of Business \& Industrial Marketing. ISSN: 0885-8624 Year: May 2004 Volume: 19, Issue: 3 Page: 197-207 DOI: 10.1108 / 08858620410531333 Publisher: Emerald Group Publishing.

Rod B. McNaughton, Phil Osborne, Brian C. Imrie. 2002. Market-oriented value creation in service firms. Journal: European Journal of Marketing. ISSN: 0309-0566. Year: Oct 2002 Volume: 36 Issue: 9/10 Page: 990 - 1002. DOI: 10.1108 / 03090560210437299. Publisher: MCB UP Ltd. 
Roderick D. Iverson, Colin S. McLeod, Peter J. Erwin. 2006. The role of employee commitment and trust in service relationships. Journal: Marketing Intelligence \& Planning. ISSN: 0263-4503 Year: Jun 2006 Volume: 14, Issue: 3 Page: 36-44 DOI: 10.1108 / 02634509610117348 Publisher: MCB UP Ltd.

Roland T. Rust, AJ Zahorik, Keiningham TL 1996, Service Marketing, Harper Collins College Publishers, New York, p.11)

Roger Bennett, Helen Gabriel. 2001. Reputation, trust and supplier commitment: the case of shipping company/seaport relations. Journal of Business \& Industrial Marketing. ISSN: 0885-8624 Year: Nov 2001 Volume: 16, Issue: 6 Page: 424-438 DOI: 10.1108 / EUM0000000006018 Publisher: MCB UP Ltd.

Rosadi Ruslan.2003. Programs and Marketing Strategy. Salemba Four. Jakarta.

Rust, Roland T., et. al., 2000, Driving Customer Equity: How Customer Lifetime Value is Reshaping Corporate Strategies. Free Press: New York

Have now, Uma 2003, Research Methods for Business, International Edition, Prentice-Hall, USA.

Sheth, JN, Sisodia, RS, \& Sharma, A. 2000. The antecedents and consequences of customercentricc marketing. Academy of Marketing Science Journal, 28, 55- 66.

Sofyan Arief. 2012. Procurement of Infrastructure with the PPP scheme. Legality Journal Vol. 20, No. 2.

Spiros P. Gounaris. 2002. Trust in industrial service relationships: behavioral consequences, antecedents and the moderating effect of the duration of the relationship. Journal of Services Marketing. ISSN: 0887-6045 Year: Dec 2002 Volume: 16, Issue: 7 Page: 636655 DOI: 10.1108 / 08876040210447351 Publisher: MCB UP Ltd.

Stanton, William J, et al, 2002, Fundamentals of Marketing, 10 th edition Grawhill Mc International, Singapore

Storbacka, Kaj \& Jarmo R. Lehtinen. 2001, Customer Relationship Management: Creating Competitive Advantage Through Win-Win Relationship Strategies. McGraw-Hill: Singapore.

Stromback, Jesper and Spiro Kiousis. Public 2013. Political Relations, New Theory-Building. Public Relations Journal Vol. 7, No. 4. The Public Relations Society of America.

Cho Sung-Eui, Kwangtae Park. 2003. Characteristics of the product/service process and geographical accessibility of customer trust in electronic commerce. Journal: International Journal of Service Industry Management. ISSN: 0956-4233. Year: Dec 2003 Volume: 14, Issue: 5 Page: 520 - 538. DOI: 10.1108 / 09564230310500200. Publisher: MCB UP Ltd. 
Tanner, Jr., John F., 1998, Users' role in the purchase: their influence, satisfaction, and desire to Participate in the next purchase, Journal of Business and Industrial Marketing; Volume 13 No. 6. MCB University Press, London

Thomas N. Garavan. 2006. Interpersonal skills training for quality service interactions. Journal: Industrial and Commercial Training. ISSN: 0019-7858. Year: June 2006 Volume: 29, Issue: 3 Page: 70 - 77. DOI: 10.1108 / 00197859710165056 . Publisher: MCB UP Ltd

UU no. 22 and 25 of 1999 on Local Government and Financial Balance between Central and Regional.

UU no. 32 of 2004 on Regional Government has the power to make the Regional Regulation (Perda) to the House of Representatives (DPRD)

UU no. 22 of 2003 concerning the composition and the MPR / DPR / D / DPD

Usmara, A. (editor). 2003 Handbook of Organizations: Research and Theory of Organization, Amara Books, Jogyakarta.

Uyung Sulaksana. 2003. Supporting Public Relations Event Marketing Program. Journal of Humanities ubuntu. Bandung.

Walker, Orville C., Harper W. Boyd, and Jean Claude Larreche 2009, marketing Strategy: Planning and Implementation, Six Edition, Irwin McGraw-Hill, Boston.

Zeithaml, Valarie E., Bitner, Mary Jo, 2001 Services Marketing: Integrating Customer Focus Across the Firm, 2nd edition, McGraw Hill Companies Inc. 